\title{
The Behavior of Speculators in the Stock Exchange of Thailand
}

\author{
Apisit Kaewcha
}

\begin{abstract}
There were a great number of speculators in The Stock Exchange of Thailand. This study investigates the behavior of speculators who traded stocks. The data were collected from speculators in many trading halls in Bangkok and traded via internet by questionnaire and observation. Convenient sampling randomly chose 484 speculators. From the study, most had five to six years' experience in stock trading and they had not been satisfied with stock trading but continued trading over the past years. They would take 21- $30 \%$ of their income for stock trading and expected that they would gain profits from capital gain. They held stocks for less than one week. They traded stocks in the amount of cash limit from 100,000 to 500,000 Thai baht and traded stocks daily. They opened cash account, cash balance and credit balance. They opened cash account, cash balance and credit balance. Their decision making in trading stock were Candlesticks, Moving average and Support /Resistance level respectively.
\end{abstract}

Keywords - Retail investors, Behavior of speculators, Technical analysis, The Stock Exchange of Thailand

\section{INTRODUCTION}

The Stock Exchange of Thailand (SET) has started its trading since April 30, 1975. In the early period, there were 16 registered stocks while there were more than 1,936 registered stocks from 649 listed companies in the present (As of 31 August 2016). In 2015, the number of trading in Thailand was highest among Asian countries (44,302 million baht per day). At the end of 2015, there were 797,326 trading accounts and from the total accounts, $25.98 \%$ were active accounts. However, from trading accounts, local investors accounted for $54.99 \%$ of the total trading value. There were a great number of local investors who were retail investors (investor, speculator and gambler). Studying behavior of speculators is beneficial to the administrators of the Stock Exchange of Thailand; therefore, it is necessary to explore each pattern of the speculators' behaviors in stock trading and the data and instruments that the speculators use in making a decision for stock trading.

\section{LITERATURE REVIEW}

Reference [1] revealed that the fundamental analysis and

Apisit Kaewcha: Faculty of Administration and Management, King Mongkut's Institute of Technology Ladkrabang, Thailand, (corresponding author's phone: +6689127 5660; e-mail: apisitkaewcha@ hotmail.com). technical analysis were employed in decision making. Regarding fundamental analysis, the investors got information from business newspapers, stock newspapers and daily newspapers and all documents in the trading halls. Regarding technical analysis, the investors gain knowledge from the training courses and the review of broker analysts. Both fundamental and technical analysis had moderate effects on their decision making.

Reference [2] studied the security investment behavior of individual investors. The major factor affecting the investors' decision making in buying or selling securities was the consideration of the value and trading volume. Regarding the problem of investment, individual investors preferred to invest in a short term. They expected to earn capital gain, not dividend. Moreover, the net settlement and the purchase of liquidity stock were the most popular behavior in security investment. The mistakes in investment were caused by believing in the rumors and speculating.

Reference [3] studied the investment behavior in The Stock Exchange of Thailand of individual investors in Chiangmai Trading Rooms. The finding revealed that the investors relied on basic assumption and technical analysis for their decision in launching on investment. The broker's printed materials on speculative deal are somewhat correct and precise; information service is also abundantly available through various mass media.

\section{RESEARCH METHOD}

\section{Data Collection}

The sources of data in this study were divided into primary data and secondary data. Primary data were obtained from the questionnaire and observation for retail investors who traded stocks at many trading halls in Bangkok and traded via internet in 2013 - 2014. Secondary data were collected from the relevant documents from previous studies done by others.

\section{Sample and Sampling}

The participants of the study were 484 speculators of stock trading at many trading halls in Bangkok and traded via internet. Convenient sampling randomly chose them.

\section{Data Analysis}

Descriptive statistics such as frequency, percentage, mean and standard deviation were employed in the analysis of the data regarding the respondents' information.

\section{RESEARCH RESULTS}

\section{Background Information of the Participants}

In this study, from 484 participants there were 200 males $(41.3 \%)$ and 284 females $(58.7 \%)$. Of the total participants, $40.5 \%$ of them were between $31-40$ years old, $37.6 \%$ and 
17.8\% were between 21-30 and 41-50 years old respectively. $59.7 \%$ of the participants were single. Of the total participants, $72.3 \%$ held bachelor's degrees while $18.6 \%$ held master's degrees. $70.2 \%$ were employees in private companies and $14.3 \%$ were business owners. Also, $43.7 \%$ of the participants earned the income around 15,000- 35,000 Thai baht per month while $28.7 \%$ earned 35,001- 55,000 Thai baht and $11.4 \%$ earned 55,001-75,000 Thai baht per month.

\section{Experience in Stock Trading}

From the study, $35.1 \%$ had 5-6 years' experience in stock trading while $28.9 \%$ and $20.2 \%$ had $1-2$ and 3-4 years' experience in stock trading respectively (Table I).

TABLE I

EXPERIENCE IN STOCK TRADING

\begin{tabular}{ccc}
\hline \hline Experience (years) & $\begin{array}{c}\text { Number } \\
\text { (persons) }\end{array}$ & Percentage \\
\hline $1-2$ & 140 & 28.9 \\
$3-4$ & 98 & 20.2 \\
$5-6$ & 170 & 35.1 \\
$7-8$ & 27 & 5.6 \\
$8-9$ & 20 & 4.2 \\
More than 10 & 29 & 6.0 \\
Total & 484 & 100.0 \\
\hline \hline
\end{tabular}

3. Satisfaction for the Stock Trading Outcome during the Past Years

Satisfaction for the stock trading outcome during the past years, $40.3 \%$ of the participants were not satisfied but continued trading, $28.9 \%$ were satisfied with their trading, $20.7 \%$ were not satisfied and decided to stop trading, and $10.1 \%$ had a neutral response for their trading (Table II).

TABLE II

SAtisfaction For The Stock Trading Outcome During The PASt YeAR

\begin{tabular}{lccc}
\hline \multicolumn{1}{c}{ Items } & $\begin{array}{c}\text { Number } \\
\text { (persons) }\end{array}$ & Percentage \\
\hline Not satisfied but continued trading & 140 & 40.3 \\
Satisfied & 98 & 28.9 \\
Not satisfied and decided to stop trading & 170 & 20.7 \\
Neutral response & 27 & 10.1 \\
& Total & 484 & 100.0 \\
\hline \hline
\end{tabular}

4. Budget for Stock Trading

In investigating how the participants budget their money for stock trading, the study showed that $30.6 \%$ of the participants spent $21-30 \%$ of their income on trading, $28.7 \%$ spent $11-20 \%$ of their income on trading, and only $11.4 \%$ spent more than $50 \%$ of their income on trading (Table III).

TABLE III BUDGET FOR STOCK TRADING

\begin{tabular}{ccc}
\hline \hline $\begin{array}{c}\text { Percentage of income on } \\
\text { stock trading }\end{array}$ & $\begin{array}{c}\text { Number } \\
\text { (persons) }\end{array}$ & Percentage \\
\hline Less than 10 & 61 & 12.6 \\
$11-20$ & 139 & 28.7 \\
$21-30$ & 148 & 30.6 \\
$31-40$ & 45 & 9.3 \\
$41-50$ & 36 & 7.4 \\
More than 50 & 55 & 11.4 \\
Total & 484 & 100.0 \\
\hline \hline
\end{tabular}

5. Spending the Income Earned from the Speculation

In investigating how the income earned from the speculation was spent, the study revealed that $27.3 \%$ of the participants spent the money in emergency, $20.2 \%$ spent their money on doing business, $18.4 \%$ spent their money on their/ their family's education, and $12.0 \%$ saved the money for their retirement (Table IV).

TABLE IV

SPENDING THE INCOME EARNED FoRm THE SPECULATION

\begin{tabular}{lcc}
\hline \hline \multicolumn{1}{c}{ Items } & $\begin{array}{c}\text { Number } \\
\text { (persons) }\end{array}$ & Percentage \\
\hline In emergency & 132 & 27.3 \\
Do business & 98 & 20.2 \\
Their / their family's education & 89 & 18.4 \\
For their retirement & 58 & 12.0 \\
Their / their family's daily expenses & 45 & 9.3 \\
Houses/ cars & 35 & 7.2 \\
Continue their trading & 24 & 5.0 \\
Others $\quad 3$ & 0.6 \\
\multicolumn{1}{c}{ Total } & 484 & 100.0 \\
\hline \hline
\end{tabular}

\section{The Expectation of the Speculators for the Benefits Gain}

According to the study, there were various kinds of benefits expected by the speculators. The study indicated that $88.8 \%$ of the participants expected the profit from capital gain, 9.9\% would like to gain dividends, and $1.3 \%$ would like to gain the benefits from tax (Table V). This study is in accordance with [2]-[3] showed that retail investors tended to be short term speculators in stock trading rather than long term investors who expected dividends. Regarding [4], 40\% of new investors wanted profits, $30 \%$ wanted savings, $20 \%$ wanted dividends, and $10 \%$ wanted to be shareholders from their investment.

TABLE V

The EXPECTATION Of THE SPECUlators For The Benefits Gain

\begin{tabular}{lccc}
\hline \hline \multicolumn{1}{c}{ Items } & $\begin{array}{c}\text { Number } \\
\text { (persons) }\end{array}$ & Percentage \\
\hline Capital gain & 430 & 88.8 \\
Dividend & 48 & 9.9 \\
Benefit from tax & 6 & 1.3 \\
$\quad$ Total & 484 & 100.0 \\
\hline \hline
\end{tabular}

\section{Average Lengths of Time in Stock Holding}

The study showed various lengths of time that stocks were held by speculators in the sampling group. Most participants held stocks for less than 1 month. Of the total participants, $49.8 \%$ held stocks for less than one week on average, 31.4\% had stock trading within one day, and $14.9 \%$ held stocks from one week to one month (Table VI). The result of this study is similar to that of [2] which indicated that retail investors were likely to have a short term investment; they sold and bought stocks within one day.

TABLE VI Average Lengths Of Time In StOck Holding

\begin{tabular}{ccc}
\hline \hline Lengths of time & $\begin{array}{c}\text { Number } \\
\text { (persons) }\end{array}$ & Percentage \\
\hline 1 day & 152 & 31.4 \\
Less than 1 week & 241 & 49.8 \\
1-4 weeks & 72 & 14.9 \\
More than 1-3 months & 12 & 2.5 \\
More than 3-6 months & 5 & 1.0 \\
More than 6-1 year & 2 & 0.4 \\
Total & 484 & 100.0 \\
\hline \hline
\end{tabular}

8. The Cash Limit in Stock Trading 
In this study, the cash limit was ranged into 7 levels. When considering the cash limit in trading stocks, the study revealed that $52.1 \%$ of the participants had a total amount of 100,000 500,000 Thai baht. $24.1 \%$ and $10.8 \%$ of them had_a total amount of $600,000-1,000,000$ Thai baht and 1,100,000 $2,000,000$ Thai baht respectively (Table VII). The result of this study is similar to that of [5] which showed that most investors invested their money not more than 500,000 Thai baht in trading.

TABLE VII

THE CASH LiMIT IN STOCK TRADING

\begin{tabular}{ccc}
\hline \hline $\begin{array}{c}\text { Cash limit } \\
(1,000 \text { Thai Baht) }\end{array}$ & $\begin{array}{c}\text { Number } \\
\text { (persons) }\end{array}$ & Percentage \\
\hline $100-500$ & 252 & 52.1 \\
$600-1,000$ & 119 & 24.6 \\
$1,100-2,000$ & 52 & 10.8 \\
$2,100-3,000$ & 21 & 4.3 \\
$3,100-4,000$ & 12 & 2.5 \\
$4,100-5,000$ & 21 & 4.3 \\
$5,100-10,000$ & 7 & 1.4 \\
Total & 484 & 100.0 \\
\hline \hline
\end{tabular}

9. The Type of Accounts Opened by Speculators for Stock Trading

The study indicates that the type of accounts opened by speculators for stock trading, $18.5 \%$ of them open only cash account, $78.5 \%$ open both cash account and cash balance, and $2.9 \%$ open cash account, cash balance and credit balance. Most of them $(75.5 \%)$ have trading via cash balance only (Table VIII).

TABLE VIII

THE Type OF ACCOUNTS OPENEd By SPECULATORS For STOCK TRAding

\begin{tabular}{|c|c|c|}
\hline Types & $\begin{array}{c}\text { Number } \\
\text { (persons) }\end{array}$ & Percentage \\
\hline Cash account & 90 & 18.5 \\
\hline Cash account, Cash balance & 380 & 78.5 \\
\hline $\begin{array}{l}\text { Cash account, Cash balance, Credit } \\
\text { balance }\end{array}$ & 14 & 2.9 \\
\hline Total & 621 & 100.0 \\
\hline
\end{tabular}

10. Stock Trading Tools for the Speculators

\subsection{Fundamental Analysis}

\subsubsection{The Fundamental Analysis Used in Trading Stock}

The results of the study reveal that the fundamental factors regarding economic analysis were considered, $13.3 \%$ of the sample group focused on the economic situation. Regarding industry analysis was considered, $12.1 \%$ focused on the type of business. Also, for company analysis, $17.2 \%$ focused on stock's market price, $7.7 \%$ on business reputation, and $5.3 \%$ on the administrator/business owner. Lastly, regarding political analysis, $15.8 \%$ focused on the political situation and $11.7 \%$ on government policy (Table IX).

10.1.2 The Understanding in the Data regarding the Fundamental Analysis

The results of the study reveal that $22.1,26.0$, and $46.1 \%$ of the sample group had understanding in the data regarding the fundamental analysis in a high, moderate, and low level respectively while $5.8 \%$ of them had no understanding about it (Table X).
TABLE IX

THE Fundamental ANALYSIS USED IN TRADING Stock

\begin{tabular}{lcc}
\hline \multicolumn{1}{c}{ Fundamental factors } & $\begin{array}{c}\text { Number } \\
\text { (answers) }\end{array}$ & Percentage \\
\hline $\begin{array}{l}\text { Economic analysis } \\
\text { The economic situation }\end{array}$ & 76 & 13.3 \\
The trend of interest rate & 38 & 6.7 \\
Industry analysis & & \\
The type of business & 69 & 12.1 \\
Company analysis & & \\
Business policy & 14 & 2.5 \\
Stock's market price & 98 & 17.2 \\
Business performance & 24 & 4.2 \\
The administrator/ Business owner & 30 & 5.3 \\
Business reputation & 44 & 7.7 \\
Dividend payment & 20 & 3.5 \\
Political analysis & & \\
Political situation & 90 & 15.8 \\
Government policy & 67 & 11.7 \\
\multicolumn{1}{c}{ Total } & 570 & 100.0 \\
\hline \hline
\end{tabular}

${ }^{\mathrm{a}}$ Can give more than one answer

TABLE X

THE UNDERSTANDING IN THE FUNDAMENTAL ANALYSIS

\begin{tabular}{lccc}
\hline \hline \multicolumn{1}{c}{ Results } & $\begin{array}{c}\text { Number } \\
\text { (persons) }\end{array}$ & Percentage \\
\hline High level & 107 & 22.1 \\
Moderate level & 126 & 26.0 \\
Low level & 223 & 46.1 \\
No understanding & 28 & 5.8 \\
\multicolumn{2}{r}{ Total } & 484 & 100.0 \\
\hline \hline
\end{tabular}

10.1.3 The Source of the Data regarding the Fundamental Analysis

The results of the study reveal that the sample group obtained the data of fundamental analysis from business newspapers / newspapers of stock, radio/TV, and websites of broker companies were 26.6, 18.2, and $17.9 \%$ respectively (Table XI).

TABLE XI

ThE SOURCE OF The DATA REgaRding The Fundamental ANALYsIS

\begin{tabular}{|c|c|c|}
\hline Sources & $\begin{array}{l}\text { Number } \\
\text { (persons) }{ }^{\mathrm{a}}\end{array}$ & Percentage \\
\hline Business newspapers/ Stock newspapers & 165 & 26.6 \\
\hline Radio/TV & 113 & 18.2 \\
\hline Websites of broker companies & 111 & 17.9 \\
\hline Documents in the brokers' trading halls & 90 & 14.4 \\
\hline Daily newspapers & 82 & 13.2 \\
\hline Websites of SET & 52 & 8.4 \\
\hline Websites of efinancethai.com & 8 & 1.3 \\
\hline Total & 621 & 100.0 \\
\hline
\end{tabular}

${ }^{\mathrm{a}}$ Can give more than one answer

10.2 Technical Analysis

10.2.1 The Technical Analysis Instruments for Decision Making in Trading Stock

The study reveals that the technical analysis instruments employed by the sample group for their decision making in trading stock were candlestick, moving average, and support level/resistance level which accounted for 19.0, 18.1, and $15.6 \%$ respectively. (Table XII)

\subsubsection{The Understanding in the Technical Analysis}

The study reveals that $35.6,32.7$, and $25.0 \%$ of the sample group had understanding of the data regarding the technical analysis in a high, moderate, and low level respectively while $6.7 \%$ of them had no understanding about it (Table XIII). 
TABLE XII

THE TECHNICAL ANALYSIS INSTRUMENTS FOR DECISION MAKING

\begin{tabular}{lcc}
\hline \hline \multicolumn{1}{c}{ Fundamental factors } & $\begin{array}{c}\text { Number } \\
(\text { answers) }\end{array}$ & Percentage \\
\hline Candlestick & 389 & 25.6 \\
Moving average & 310 & 20.4 \\
Support level/Resistance level & 252 & 16.6 \\
RSI & 152 & 10.0 \\
MACD & 120 & 7.9 \\
Trend line & 110 & 7.2 \\
Stochastic & 96 & 6.3 \\
Graph patterns & 64 & 4.2 \\
On balance volume, Volume & 22 & 1.4 \\
Fibonacci ratio & 5 & 0.4 \\
\multicolumn{1}{c}{ Total } & 570 & 100.0 \\
\hline \hline Can give more than one answer & TABLE XIII & \\
\multicolumn{2}{c}{ THE UNDERSTANDING IN THE TECHNICAL ANALYSIS } \\
\hline \hline
\end{tabular}

10.2.3 The Source of Knowledge regarding the Technical Analysis

The study indicates that the sample group obtained the knowledge of the technical analysis from the analysis of broker analysts, pocket books concerning the technical analysis, and information from marketing officers for 37.6, 22.3, and 19.7\% respectively (Table XIV).

TABLE XIV

The Source Of KNOWLEdge Regarding THe TeChNicAl ANALysis

\begin{tabular}{lcc}
\hline \hline \multicolumn{1}{c}{ Sources } & $\begin{array}{c}\text { Number } \\
\text { (persons) }\end{array}$ & Percentage \\
\hline Analysis of broker analysts & 340 & 37.6 \\
Pocket books concerning the technical & 202 & 22.3 \\
analysis & 178 & 19.7 \\
Information from marketing officers & 70 & 7.7 \\
Training courses & 62 & 6.9 \\
Business newspapers/ Stock newspapers & 52 & 5.8 \\
Courses taken in the university & 904 & 100.0 \\
\multicolumn{2}{c}{ Total } & \\
\hline \hline
\end{tabular}

${ }^{\mathrm{a}}$ Can give more than one answer

\section{REFERENCES}

[1] K. Apisit, "The Instruments Employed in Decision Making by Retail investors in The Stock Exchange of Thailand", International journal of Business and Management Studies, vol. 2(3), 2013, pp.165-173.

[2] P. Nopjiraamporn, "Security Investment Behavior of Individual Investors in The Stock Exchange of Thailand", Thesis. Sukhothai Thammathirat Open University, Thailand. 2003.

[3] W. Chaiwan, "Investment Behavior in The Stock Exchange of Thailand by Individual Investors in Chiang Mai Trading Rooms", Thesis. Chiang Mai University, Thailand. 2005.

[4] S. Potin, "A Requirement Information and Suggestion for the High Net Worth Investors: A Case Study of Para Security Company", Thesis. Kasem Bandit University, Thailand. 1996.

[5] B. Suksomboon, "Factors Effecting the Investment Decision Making in The Stock Exchange of Thailand", Thesis. University of Thai Chamber of Commerce, Thailand. 2001.

[6] The Stock Exchange of Thailand. Annual Report. [Online]. Available : http://www.set.or.th/en/about/annual/annual_p1.html. 2016.
Apisit Kaewcha was born in Samutsongkarm Province, Thailand. He received a B.Sc. in Agriculture Economics from Kasetsart University, Thailand. He received a M.Sc in Agriculture Economics from Kasetsart University, Thailand.

$\mathrm{He}$ is an assistant professor at faculty of Administration and Management, King Mongkut's Institute of Technology, Ladkrabang (KMITL), Thailand. He has published articles in International Journal of Arts and Sciences and International Journal of Business and Management Studies. His current research in the broad area of marketing, consumer behavior, and investment. 